\title{
Blockchain-Based Wine Supply Chain for the Industry Advancement
}

\author{
Nino Adamashvili ${ }^{1, *} \mathbb{C}$, Radu State $^{2}$, Caterina Tricase ${ }^{1}\left(\mathbb{D}\right.$ and Mariantonietta Fiore ${ }^{1}$ \\ 1 Department of Economics, University of Foggia, 71121 Foggia, Italy; caterina.tricase@unifg.it (C.T.); \\ mariantonietta.fiore@unifg.it (M.F.) \\ 2 Interdisciplinary Centre for Security, Reliability and Trust (SnT), University of Luxembourg, \\ 1855 Luxembourg, Luxembourg; radu.state@uni.lu \\ * Correspondence: nino.adamashvili@unifg.it or nino_adamashvili@yahoo.com
}

check for updates

Citation: Adamashvili, N.; State, R.; Tricase, C.; Fiore, M. Blockchain-Based Wine Supply Chain for the Industry Advancement. Sustainability 2021, 13, 13070. https://doi.org/10.3390/ su132313070

Academic Editors: Alessio Ishizaka and Claudia Colicchia

Received: 24 September 2021 Accepted: 19 November 2021 Published: 25 November 2021

Publisher's Note: MDPI stays neutral with regard to jurisdictional claims in published maps and institutional affiliations.

Copyright: (c) 2021 by the authors. Licensee MDPI, Basel, Switzerland. This article is an open access article distributed under the terms and conditions of the Creative Commons Attribution (CC BY) license (https:// creativecommons.org/licenses/by/ $4.0 /)$.

\begin{abstract}
The wine sector is one of the most 'amazing' and significant agri-food sectors worldwide since ancient times, considering revenue or employment as well as health aspects. This article aims to describe the impact of the implementation of blockchain technology (BCT) in the wine supply chain After the literature review, the study is based on Agent Based Models (ABMs) and carried out by the GAMA program. Then, the model and simulation of BCT wine supply chain is designed. Finally, the paper compares traditional and BCT-based supply chains, and the advantages of the last one are evident. Blockchain is a useful tool to ensure a traceability system and to protect the production from any type of fraud and contamination.
\end{abstract}

Keywords: blockchain technology; wine; supply chain; traceability; time-to-recall

\section{Introduction}

Today's society continues to place growing importance on health and wellness and address issues surrounding them, taking responsibility for a healthy lifestyle. The attitudes and demand for higher quality have changed considerably [1,2]. Consequently, an important issue is the process of food and beverage production and its perfection [3]. Therefore, in the recent times, agricultural policies have aimed to produce higher quality products.

Still, as reported by WHO [4], an estimated 600 million people in the world become ill and 420 thousand die yearly because of eating contaminated products. In turn, it causes lower productivity of the people and higher healthcare costs [5,6]. These numbers are motivated by the fact that certain bacteria not only damage the product, but they can also be transmitted to humans [7].

On the other hand, globalization has caused the complication of supply chains as they have gotten longer. They contain more participants from suppliers to final consumers. This caused the complexity of finding a bottleneck through the supply chain and provoked the simplicity of falsification of products [8,9]. Difficulties in tracing the product timely may result in spreading the contaminated goods on the market and problems of identifying affected items. As a result, the producer may become forced to recall a greater amount of products and may be under the risk of losing the reputation as well [10]. Therefore, the information about each stage of supply chain acquires greater importance.

According to Martins-Lopes and Gomes [11], special attention is focused on the products with PDO (Protected Designation of Origin), PGI (Protected Geographical Indication) or TSG (Traditional specialty guaranteed). In these cases, the information about geographical and climate conditions, production techniques, and alike matters, is extremely valuable as they guarantee the characteristics, safety, and quality of products. One of the most sensitive products in this regard, is wine $[12,13]$. The quality of wine depends on the grape sort; the zone where the grape is grown; its treatment; when the grape is picked up and crushed; the production process and environment including the variation of temperature 
and utensils in which the liquid is prepared; if there is any mistake in bottling and packaging; storage; and transportation conditions. A little error in any stage can result in the failure of the product [14-19]. Subsequently, the transparency of all processes through the wine supply chain is becoming crucial for each participant of the supply chain and especially for final consumers [20].

In order to be able to achieve this mission, modern software innovations need to play a crucial part in the overall process [21]. Meaning, a corresponding software and hardware can be complemented towards determining challenges, avoiding those obstacles in short time periods, and making overall process of bringing the products to the customer as efficiently as possible.

The main obstacles that arise usually are the lack of information, its falsification, or unreliability $[22,23]$. Ultimately, the absence of necessary information or its inaccessibility may cause a negative impact on product quality and reliability, and subsequently, on the health of consumers [24]. At such times, the emerging technologies play a crucial role. They allow the information to be accessible and controlled in a short period of time. This is happening through the digitization of data and the acceleration of industry and society $[25,26]$.

Despite the fact that the emerging technologies can digitalize the data and make it accessible, the reliability of the information still remains as a challenge [27]. So, it should not remain out of consideration. It is necessary to be sure that the information provided by governments, suppliers, producers, as well as other external entities such as IoT companies, is reliable, complete, immaculate, and not falsified [28,29]. In order to achieve this condition, having a centralized system can be an impediment. There is a high potential for central authority to forge the information according to their own illegitimate interests. [30] Additionally, the usage of invalid, misinterpreted, or unrelated data while performing the data analysis can result in less accurate outputs, expectations, or system behavior, which will affect the total productivity of the agricultural system under analysis [31].

The purpose of the paper is (1) to describe the blockchain technology (BCT), its different types and characteristics with their advantages and disadvantages; (2) to bring the light to the structure, main issues, necessities, and requirements of modern supply chains; and (3) additionally, the aim is to investigate the impacts that could have BCT if it is adopted by the industries. Starting from the analysis of the literature review and from the study of Agent Based Models (ABMs) and of the potentials of the GAMA program, the model and simulation of BCT-based wine supply chain is designed. Finally, the paper compares traditional and blockchain-based supply chains. Therefore, the research question is as follows: could Blockchain-based supply chain be more effective than the traditional chain in terms of information sharing, and time and costs of tracking back the products? Can BCT, thanks to its transparent nature, have the ability to minimize disorganization and inefficiencies along the supply chain that may cause disastrous results?

The work is structured as follows: The next section deals with relevant literature in the field. First of all, the blockchain technology is described, and its Public and Private forms are differentiated. Then the implementation of BCT in supply chains is discussed by successively comparing the traditional and non-traditional wine supply chain. The next section explains the methodology of the study that includes the empirical analysis as a first step of the research methodology: Successively, in order to visualize the results of the case study, an Agent-Based Modeling and Simulation (ABMS) using the program GAMA is implemented. Results and discussions follow the flow describing and deepening the framework linked to the findings. Finally, the conclusion section closes the article.

\section{Literature Review}

\subsection{Blockchain Technology-General Description}

"Blockchain is a distributed ledger maintaining a continuously growing list of data records that are confirmed by all of the participating nodes" [32]. Blockchain technology is a 
digital ledger of records, called "transactions", secured with a hash function, authenticated, and maintained through a distributed network of nodes using a consensus protocol [33]. Nodes are all participants involved in the blockchain, each one has a copy of the blockchain and equal authority to accept or not the new blocks [34]. The new blocks are added on the blockchain if all nodes achieve consensus on the transaction. An indestructible chain is formed, since once the new line (block) is added on the blockchain and proved from all nodes applying the hash function, it is not possible to change even a little detail in the older data by any single participant $[35,36]$. Therefore, as any distributed ledger technology (DLT), blockchain enables parties who do not trust or even not know each other, to interact on a peer-to-peer basis without any need of third-party authorities, and to exchange the data in a secure way. In the blockchain, parties trust each other on the basis of a consensus mechanism - a set of the rules that should be followed by each of the nodes to verify and validate the transaction and to add the block on a chain [37].

One way to provide reliable information is through a decentralized system that is trusted by all participants in the production and delivery process [38]. Also, this system should ensure data immutability. The reliability can be considered achieved, if the data is available to all participants and if they have the opportunity to verify that the data has not been falsified since its inception [39]. Besides, if there is a system that can ensure the reliability of the data, it will also be able to deliver the information securely to the recipient [40].

From this point of view, blockchain technology (BCT), the first decentralized technology originally developed for mining of cryptocurrency, has a potential to solve the problem of data reliability, transparency, and traceability, thus guaranteeing the trustworthiness of information. It represents a protocol providing the infrastructure that ensures the immutability of the information over time [27]. Because of this property, BCT has been applied in various different areas. The benefit for the food and beverage supply chain is noteworthy.

A very early beginning of blockchain technology can be found in the 90s when Haber \& Stornetta [41] introduced the work "How to time-stamp a digital document". The authors proposed two solutions in order to certify when a document was created or last modified: the hash function and the digital signature. Since these solutions time-stamp the actual bits of the document, changing even one character in this document causes the difference in hash value. So it is easy to show that the signed documents are modified.

Later, in 2008, on the basis of Haber \& Stornetta's [41] work, the blockchain technology (BCT) itself was invented by Satoshi Nakamoto as the technological basis for the Bitcoin cryptocurrency [42]. It is a decentralized digital database that allows the secure recording and sharing of all information regarding transactions, registered by different actors involved in the production and distribution processes. The main characteristics of blockchain technology are the immutability, transparency, and traceability of transactions, as well as security based on cryptographic techniques [27,43-46]. Regardless of these features, BCT remained under shadow for several years; in 2014 it began to emerge and it has continued to gain massive attention globally. This attention is shifting to different areas of uses other than money as well. Indeed, at present, BCT is among the popular topics for academic research and application in practice. Only in the first three quarters of 2016, 1.4 billion dollars were invested by startups [47].

Hence, recently, BCT has attracted increasing attention in the context of new applications. Using the BCT in various areas has made it necessary to diversify its types [48]. Each field has different requirements and restrictions. For instance, several studies [49-52] have shown that the transparent nature of BCT could be a problem in some areas. For this reason, the necessity of protecting the information from accessibility for everyone has risen. Additionally, in some cases, it is impossible to run the system in a totally decentralized and uncontrolled way. Some fields have legal requirements to know each party in the network [53]; the business sector mostly has the necessity to have the system more strictly controlled, with a restriction to modify or even read the blockchain state for several 
users [54,55]. Therefore, it becomes important to identify each node in the network. As a consequence, there are Public or Private/Permissionless and Permissioned Blockchain Technologies, described in the next section.

On the other hand, in some cases, the main requirement for the system is to minimize the latency or reduce operational cost. In this case, the consensus protocol plays a crucial role [56]. It determines the scalability of $\mathrm{BCT}$, since the computational power and consequently the time for confirming the transaction depend on the quantity of transactions in each block and the interval between blocks [57]. Individual businesses independently determine the type of $\mathrm{BCT}$ that is comfortable for their work. According to the necessities of various industries, the different features of BCT have been evolved and diverse types of BCT have been developed. Consequently, the architecture of different blockchain technologies differ from one other. The public and private blockchains are described in the following section.

\subsection{Public and Private Blockchains}

Blockchain Technology, with its classical definition, provides complete decentralization and uncontrollability of the system [58]. However, over time, the necessity of permissioned BCTs has been raised. These kinds of BCTs make a possibility to predefine the nodes involved in the system [59]. It does not mean full centralization of a system. In this case, nodes need the acceptance for joining the network. After that, the system continues to work in a decentralized manner. This function supports a better authorization and authentication processes. It eliminates the problem of privacy in transaction processes [56].

Now blockchains can be categorized into three types: public (permissionless), consortium (permissioned), and private (permissioned) blockchains. Canadian programmer Buterin Vitalik [60] describes them in his article "On Public and Private Blockchains", their characteristics (Table 1), and advantages and disadvantages (Table 2).

Table 1. Characteristics of public, consortium and private blockchains (Source: Buterin [60]; Zheng et al. [61]).

\begin{tabular}{|c|c|c|c|c|c|}
\hline & To Read & $\begin{array}{c}\text { To Send } \\
\text { Transaction }\end{array}$ & $\begin{array}{c}\text { To Participate in } \\
\text { Consensus Process }\end{array}$ & The Mechanism & Other Characteristics \\
\hline $\begin{array}{l}\text { Public } \\
\text { "fully decentralized" }\end{array}$ & anyone & anyone & anyone & $\begin{array}{l}\text { PoW (Proof of Work), } \\
\text { PoS (Proof of Stake) }\end{array}$ & $\begin{array}{l}\text { Secured by crypto economics; the } \\
\text { degree of influence is } \\
\text { proportional to the quantity of } \\
\text { economic resources }\end{array}$ \\
\hline $\begin{array}{c}\text { Consortium } \\
\text { "partially } \\
\text { decentralized" }\end{array}$ & $\begin{array}{l}\text { Anyone/pre-defined } \\
\text { nodes }\end{array}$ & pre-defined nodes & pre-defined nodes & $\begin{array}{l}\text { The majority have to } \\
\text { sign every block }\end{array}$ & \\
\hline $\begin{array}{l}\text { Private } \\
\text { "fully private" }\end{array}$ & Anyone/restricted & centralized & centralized & & $\begin{array}{l}\text { Likely applications include } \\
\text { database management, auditing, } \\
\text { etc. internal to a single company }\end{array}$ \\
\hline
\end{tabular}

Table 2. Advantages and disadvantages of public, consortium, and private blockchains (Source: Buterin [60]; Zheng et al. [61]).

\begin{tabular}{|c|c|c|}
\hline & Advantages & Disadvantages \\
\hline $\begin{array}{l}\text { Public } \\
\text { "fully } \\
\text { decentralized" }\end{array}$ & $\begin{array}{l}\text { Protects users from developers' influence; } \\
\text { Trust of the system (blockchain) } \\
\text { Censorship resistance } \\
\text { Network effect; } \\
\text { Immutability nearly impossible to tamper }\end{array}$ & $\begin{array}{l}\text { Can reduce the block time till } 15 \mathrm{~s} \text { (Ethereum) } \\
\text { instead of } 2 \mathrm{~h} \text { (Bitcoin), but still it is more than } \\
\text { in the cases of private or } \\
\text { consortium blockchains }\end{array}$ \\
\hline $\begin{array}{l}\text { Consortium } \\
\text { "partially } \\
\text { decentralized" }\end{array}$ & $\begin{array}{l}\text { Easy changes, revert transaction, modify balances; } \\
\text { The validators are known; } \\
\text { Cheap transactions; } \\
\text { Nodes can be trusted to be very well-connected; }\end{array}$ & Immutability could be tampered \\
\hline $\begin{array}{c}\text { Private } \\
\text { "fully private" }\end{array}$ & $\begin{array}{l}\text { Easy changes, revert transaction, modify balances; } \\
\text { The validators are known; } \\
\text { Cheap transactions; } \\
\text { Nodes can be trusted to be very well-connected; } \\
\text { Greater level of privacy if read permissions are restricted. }\end{array}$ & $\begin{array}{l}\text { Immutability could be tampered } \\
\text { In some cases, in order to efficiently work the } \\
\mathrm{BC} \text {, some heterogeneous assets from different } \\
\text { industries need to be on the same database, } \\
\text { which is difficult to happen in private BCs. }\end{array}$ \\
\hline
\end{tabular}


Seemingly, public blockchain is "fully decentralized", anyone can read and send transactions; consortium blockchain is "partially decentralized", anyone or pre-defined nodes can read, and only pre-defined nodes can send transactions; while private blockchain is "fully private" meaning that read permissions can be both restricted or public while the writing is centralized [60,61].

All three types of blockchain technology have their advantages and disadvantages. The users should choose the one that fits better to the requirements of a specific field of application.

\subsection{Blockchain Application in Supply Chain}

Agriculture is experiencing several environmental, economic, and social issues that push and motivate a transition towards sustainable paths within the global economic system [62-64]. Therefore, over the last decade, there was an exponential increase in promoting smart systems and in identifying ingenious solutions for all the sectors $[65,66]$. On the other hand, BCT has been found to be a revolutionizing technology for a number of different fields of the economy. One of the industries where BCT is very promising is agriculture.

The adoption of ICT in agriculture sector can certainly strengthen the large-scale transformation, decrease production costs, and increase investments growth [67]. Especially the adoption of blockchain technology promotes sustainable e-agriculture $[68,69]$. Therefore, BCT can play a fundamental role and could have a wide scope of application, taking into account the importance of knowing the origin of an agri-food product for consumers and of the usefulness of this technology to fight against counterfeiting and falsification of products.

Besides, BCT in the agricultural sector is being adopted for optimizing the processes in the supply chain; improving the traceability; enhancing food safety, and reducing times and cost of transaction, food fraud, and inefficient processes. In addition, blockchain can improve the profits of farmers and promote ethical businesses, like fair-trade, animal welfare, and reduce environmental impacts [63,70-73]. Therefore, the implementation of the BCT improves the traceability - the ability to trace and track the food through all the steps [74]. It can avoid a diffuse use of pesticides and fertilizers, which can cause the presence of residues dangerous for human health [75]. Additionally, BCT gives the ability to suppliers, farmers, producers, retailers, and governments to identify and confine contaminated elements and to follow its road along the supply chain.

It is noteworthy that thanks to abovementioned characteristics, BCT significantly reduces the time of re-call if the hazardous product appears in the retail shops. Therefore, it reduces the inefficiencies along the supply chain that may cause disastrous results $[5,6]$. Precisely detecting maleficent goods in time promotes recalling back the products before it spreads to the consumers, it does so only with the ones that are affected, so it reduces health risk, financial loss, and reputation damage $[10,76]$.

Blockchain technology influences several factors in the agricultural sector (climateenvironment related data, payments, soil-moisture, demand and sale price, seed quality, products' convenience to the farmers, equipment, finance, loans etc.) and focuses on four key aspects [77-79]:

1. Consensus and distributed trust among farmers regarding crucial rights;

2. Security in terms of safety of the data;

3. Provenance that ensures safe sure transactions and avoids fraudulent data;

4. Trust among actors that are part of a ledger within buyer-seller relationships.

Consequently, BCT collects several advantages and generates an exclusive level of credibility but some limits persist and have to be dealt with: regulations, relationships among actors, data ownership, scalability, etc. [68]. Every business of the agri-food supply chain manages its own data-recording systems; so, a unique tracking system for info appears tricky due to the mismatch among software or data structures [80]. In addition, it is necessary to highlight that the costs of skilled human resources and of developing, 
adopting, and maintaining blockchain technology can be considered higher than other systems [81].

A recent work [63] investigated BCT in the light of the COVID-19 pandemic and of weaknesses and needs that emerged in the agri-food chain: The necessity of both real-time accurate information reflecting the purchase choices and of effective coordination between actors to reply with fast and adequate responses, and the urgency of efficient processes for reducing times in bureaucracy-based procedures. The figure below (Figure 1) illustrates an improved BCT-based supply chain system that can be arranged in COVID-19 era to improve the allocation of resources when dealing with unforeseen events.

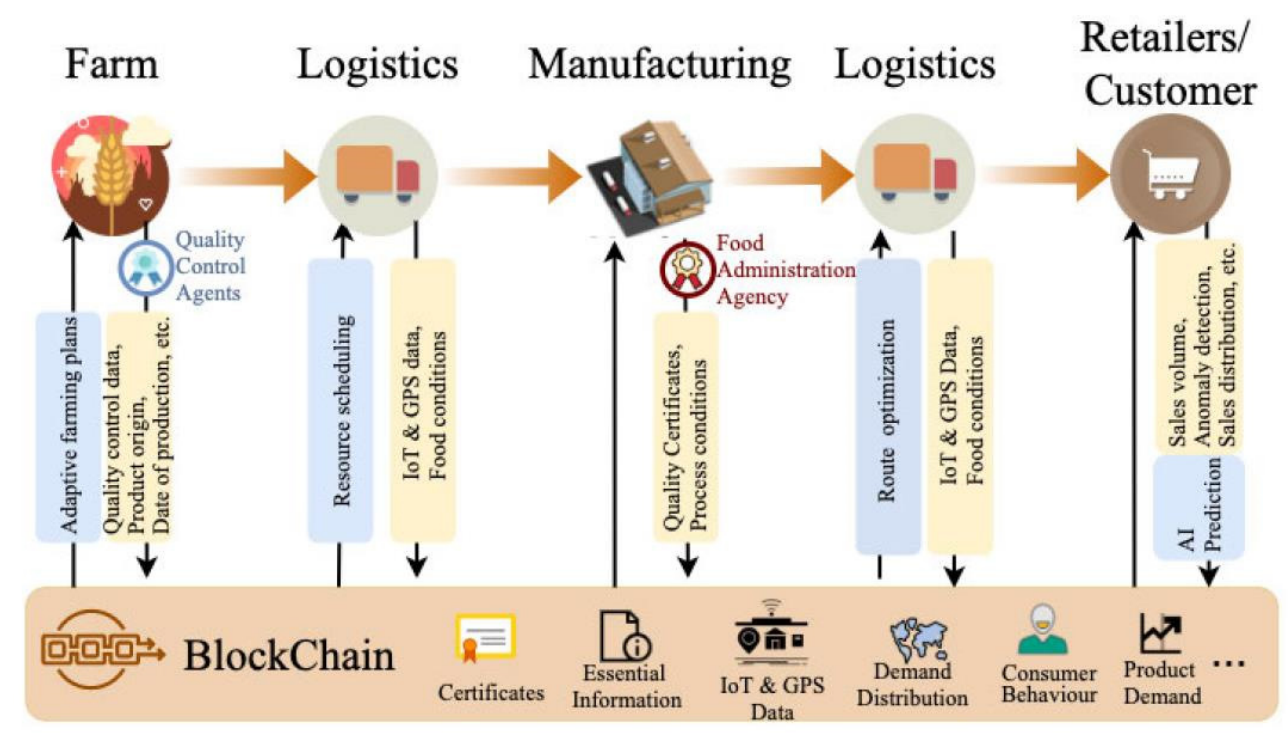

Figure 1. BCT in the COVID-19 pandemic economy (Source: Lin et al. [63]).

Another recent research [82] proposes to implement a consortium BCT-based machinery scheduling system to join the advantages of the BCT to the intelligent distributed scheduling of agricultural machinery: In this way, it is possible to overcome a single point crash, high costs, and waste of resources. On the other hand, Khan et al. [80] suggested to combine IoT (Internet of Thinks) with BCT, implementing an IoT-blockchain-enabled intelligent system taking farmers as participants and allowing them to create personnel files and duly record files for each section (see Figure 2).

In order to combine BCT to risk issues, FAO proposes an interesting scheme, FARMS (Financial and Agricultural Risk Management for Smallholders), which provides, through the $\mathrm{BCT}$, easy access to formal financial risk management, while increasing farmers' financial literacy.

To underline the fundamental role that this technology could have in the future, Italian Ministry of Economic Development launched on 18 June 2020 a public consultation to collect proposals collected in the report "Proposals for the Italian Strategy on technologies based on distributed registers and blockchain". The report reaffirms the importance of implementing a digital infrastructure based on blockchain technologies to promote the development of an ecosystem for the exchange of product information in order to increase its transparency and strengthen guarantees of origin and food safety, involving all the actors in the supply chain and the final consumer. The BCT is proposed as a transparent traceability and communication system aimed at fighting counterfeiting in the various production sectors and the spread of so-called Italian sounding, together representing valid tools for the promotion of Made in Italy above all in the agri-food sector. 


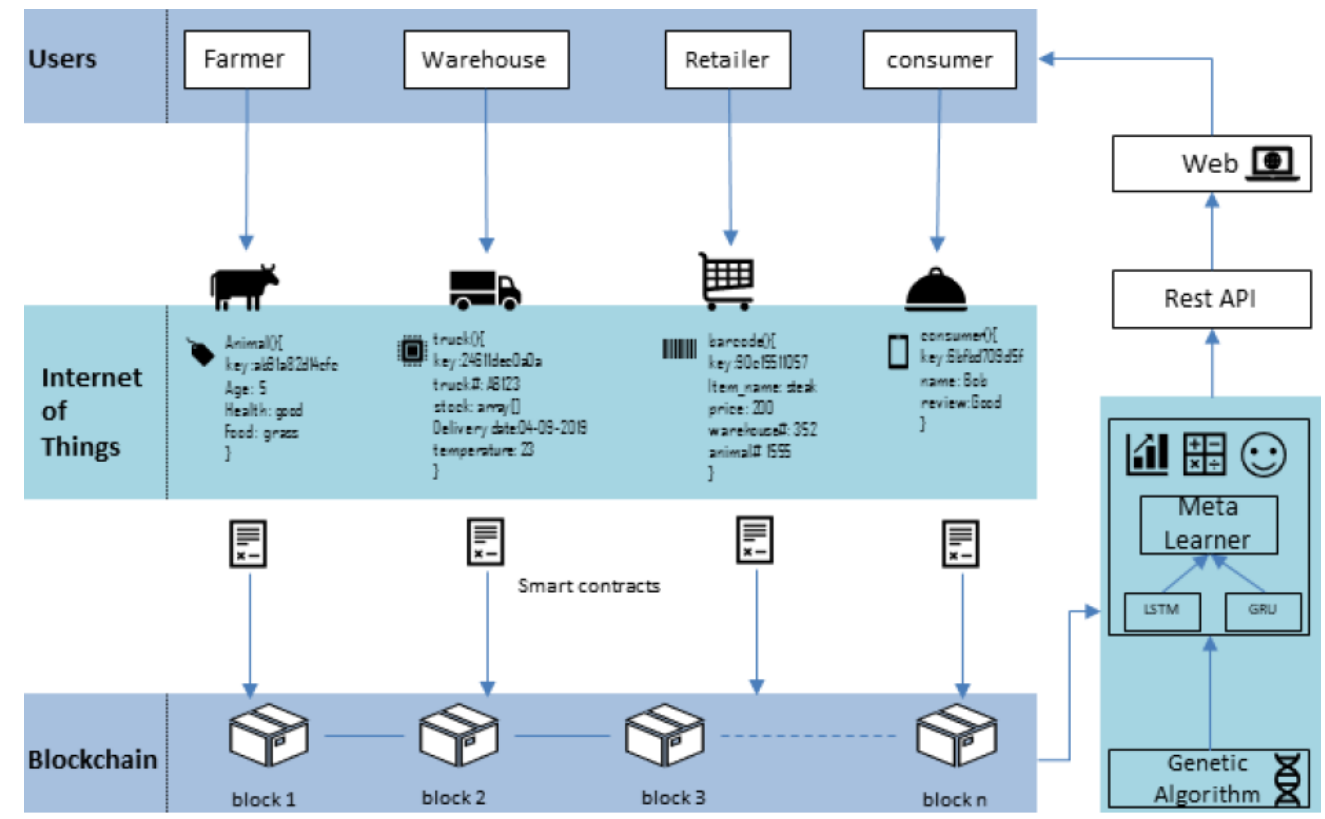

Figure 2. The IoT-blockchain-enabled intelligent system (Source: Khan et al. [80]).

In line with the above-mentioned framework, the European Green Deal by European Commission and the "Farm to Fork" strategy for a fair, healthy, and environmentallyfriendly food system aim to address in a systemic way the challenges related to the sustainability of food systems, recognizing the connections that link the health of individuals, companies, and environment. This strategy is developed around six macro-objectives, which concern the sustainability of food production phases, food security, promotion of sustainable food consumption, reduction of food losses and waste, and the fight against fraud in food supply chains.

One of the most sensitive products with features such as provenience and quality is wine. Indeed, the world of wine has always been associated with traditions related to territory and production methods, but also to sales and distribution systems. In recent years, there has been an increasing awareness on the side of wine producers. They, in order to face the increasing global international competition, have favored more and more the inclusion of production criteria aimed in particular at obtaining high quality products and the sustainability of processes, which are factors appreciated by end consumers [83]. In particular, in terms of marketing strategies, companies must adopt effective communication strategies to inform end-customers about the uniqueness of each bottle and its added value, in order to create an unconditional relationship of trust with the customer, both intermediate or final. In fact, there is an increasing tendency for consumers to seek information on the products they want to buy, and almost all of them are also prepared to incur higher costs, if this means achieving transparency in the production processes and guaranteed quality [84-86].

The blockchain solutions can ensure the traceability, transaction history, provenience, and quality standards of each bottle in a safe and immutable way. In addition, the importance of introducing BCT into the wine supply chain derives from the wine classification system on EU and national level. In fact, there are two main categories of wines: with designation of origin (PGI and PDO) and wines without this denomination (varietal wines). The difference is between wine products that maintain a close correlation with the cultivation territory and that have to follow a regulated winemaking procedures, and wines not linked to determinate areas and production processes.

In addition, adopting BCT can affect not only the traceability of the entire production process, but in particular can result in [87]:

- Consumer's feedback by means of the use of simple apps; 
- $\quad$ Customizing a reading system for customers and launching a strong commercial message;

- Reliability of information that, not being centralized, is globally available, thus allowing to protect the image of each winery that can, therefore, protect its product from fakes on the market (fight against counterfeiting);

- Automated mechanisms that allow to eliminate intermediaries, reduce waste, and increase production efficiency.

\section{Materials and Methods}

The paper includes the empirical analysis as a first step of the research methodology. It creates an overview of the state of the art of a specific topic by synthesis of different previous researches and based on their results [88]. In order to meet the research aim, numerous academic articles were identified, selected, and studied.

The core step of the methodology is the case study research. It is a popular method of qualitative analysis on the basis of real occasions. It makes the opportunity to study a complex phenomenon in natural surroundings and to elaborate theories from practical circumstances $[89,90]$. Case study methodology is appropriate to use in various instances, including when it is necessary to answer the questions "how", "what", and "why"; when it is not possible to manipulate with the research object; or when the contextual circumstances are needed to be covered because of their relevance [91]. This is the case when we cannot manipulate the research objects since each of them represent the stakeholders or group of stakeholders, and together, the whole industry. Therefore, in real time we cannot do the experiments and affect, in this way, on the economy. Besides, our research matter (wine supply chain) is very wide and contains a lot of actors and operations. In order to cover them, this paper generalizes and simplifies the wine supply chain. Therefore, this case study definitely answers the questions "how", "what", and "why". Other characteristics were provided in the article, considering the works [90-93].

Therefore, this case study provided in the paper has a specific instrumental nature and differs from the normal case study research approach according to Ketokivi and Choi, Pagell and Wu, and Eisenhardt [94-97]. It gives insight into the issue related to traditional supply chains and particularly wine supply chain [90]. In this article, one case (wine supply chain) is described with two embedded units. It compares traditional and blockchain-based supply chains and facilitates understanding differences between them. So, there is shown the wine supply chain in two different conditions, the results are analyzed accordingly [90,91], and the statement is developed. To focus on the statement is important to not lose the scope and add more credibility to the results. As for the conceptual framework, there are identified actors involved in the case, describing the relationship between them, and more precise pictures were made than could be obtained from general empirical analysis [92]. Thus, the data source is the literature like academic articles, reports, and projects that make it credible [93].

Last but not least, for simplicity and simultaneously for better visualization of the results of case study, authors decided to build an Agent-Based Modeling and Simulation (ABMS) using the program GAMA. It translates the results into solutions in a way to be simpler for the reader to understand the complex phenomenon and find solutions for a wide range of challenges. The ABMs and the software GAMA are used as supportive tools for describing the case in a very clear manner and making the impression for readers that they participated in the research. This makes clear the phenomenon itself as well as the context it takes place in [98]; ABMs are computer simulations that are composed by different kinds of agents. These agents are situated in a specific environment and circumstances and are given the ability to make decisions and act autonomously [99]. Furthermore, they have certain predefined rules on how to interact with each other in particular situations. In this way, computer simulations capture the complex matters, generate new knowledge, and explain the dynamics of the real world [100,101]. It occurs when the agents interact with each other and these interactions are defined based on their cognitive nature [99,102]. In this research, agents are the stakeholders of the wine supply chain. They collect the grape; 
produce the wine and bottle; and pack, distribute, sell, buy, and even return them back. In order to carry out these activities, agents/stakeholders interact with each other according to predefined rules.

The computer programming made its contribution for making ABMs a significant tool in order to study complicated systems. Precisely, computer programming enriches ABMs with the ability to analyze the cases with a complex nature. There are lists of the modeling and simulation platforms. According to Taillandier et al. [103], each of them are useful and more suitable for different cases; based on the research interests and objectives, researchers use different platforms. The simulation software GAMA is an open-source modelling and simulation platform. GAMA was established in 2007 and has been developing continuously by improving its features for satisfying the various and growing needs of its users in order to deal with different data formats and to increase the effectiveness and usefulness of the Software. The interface has been improved in terms of having a better view of the data, navigation bar, editor, etc. as well. Developers of GAMA tried to combine the advantages of already existing platforms and eliminate their limitations. Thus, their objective is to make it possible to build models easily and quickly like NetLogo does, and to provide as rich simulations as Repast and CORMAS do. Consequently, the modeling language GAML (GAma Modeling Language) was developed. It is simple to use and, simultaneously, it is a powerful tool for comprehensive visualization [104]. The other added value is the capacity to model spatial phenomenon. GAMA supports to build large-scale models with extensive visualization that gives the possibility to analyze the simulation results [105]. This is among the main features for agent-based simulation platforms. So, one of the advantages of software GAMA is that it makes possible to easily build even a complex model and simultaneously to visualize the result. Consequently, it is attainable to check the simulation step-by-step instead of creating the entire model and seeing only the final result. Therefore, it is easier to quickly identify the impact of the changes on the simulation and to use a test-and-try method [103]. For the reason that this paper requires the possibility to export the simulation results in the different stages of the experiment, and since the aim of the simulation is academic research and the visualization of its results in the work, the remarkable feature of the platform GAMA is its possibility to accurately export the data in different formats. Moreover, the case described in this paper simulates two different supply chains as a whole and the output for the system effectiveness. It generalizes the entire industry in a single case. Nevertheless, it does not include the variety of interactions between agents; in addition, the environmental conditions are not included in the simulation. Therefore, for simplicity and simultaneously for better visualization of the results of the case study, the authors decided to use the software GAMA. Furthermore, GAMA offers the possibility for future work to analyze the real cases and more complex models.

With other words, the simulation is fed with the information gained form the discussed literature. Indeed, all three components of the methodology are interconnected and support each other. Analyzed literature investigates the structure and current challenges of agrifood supply chains as well as the characteristics and opportunities of BCT; the case study describes the wine supply chain, main actors, and their roles in the production and supply of the final product; finally, all the information are gathered in the modelling and simulation software GAMA, where the theoretical background is reflected in the practical examples of traditional and blockchain-based supply chains' operational processes. Precisely, in the final step of the methodology, in the software GAMA, the results of literature analysis are visually clearly conveyed in a clear manner on the basis of the described wine supply chain case. Therefore, the aim of the utilization of software GAMA is to reflect the reality in the model and to highlight the difference between traditional and blockchain-based supply chains through visualization function. 


\section{Results and Discussion}

\subsection{Description of the Model and Simulation "Wine Roads"}

Based on the literature review and on the study of ABMs and the program GAMA, the model and simulation of wine supply chain was designed. The simple wine supply chain was described. It demonstrates the sequence of the processes and information exchange along the supply chain with the example of one producer company for simplicity. The case can be generalized and applied to the whole industry since the architecture is similar for every producer.

The objects of the model "Wine Roads" are as follows:

Vineyards-On the initial picture of the model (Figure 3), plantations of grape-bearing vines are shown reflecting with the grape image. Every time the program lunches, the grapes are allocated randomly. So, the experiments are different every time from each other.

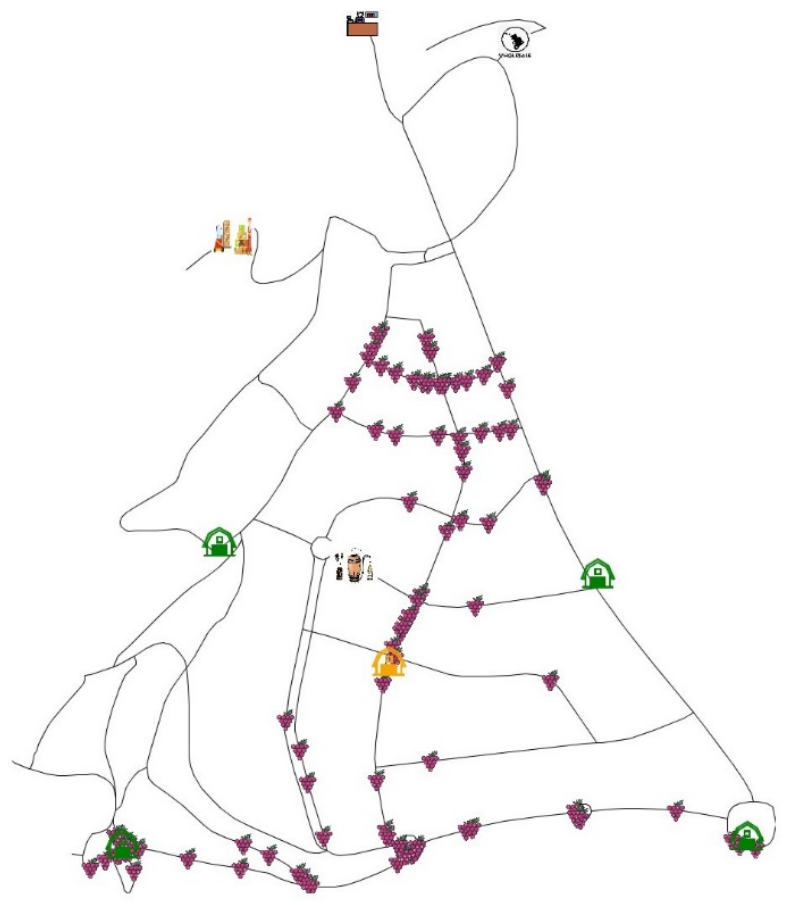

Figure 3. The model "Wine Roads": initial condition.

Grape is the fundamental material for the wine, and its quality determines the value of the final product. Therefore, the geographical and climate conditions as well as how they are treated are crucially important.

Farmers-Farmers/grape growers are responsible for the treatment of the grape, as well as for harvest and delivery. Besides, they should record all related information.

During coding the simulation, the farmer, who collects low-quality grape, is identified in the beginning and it is highlighted with the orange color, differently from other green ones (Figure 3). On the map, each farmer "owns" the territory where they are allocated. So, the grapes go to the nearest farm, and the algorithm computes and chooses the shortest paths. Because they are allocated randomly, every time the simulation runs, different amounts of low and high-quality grapes are collected by the farmers.

Processor-All the collected grapes go to the processor company. In order to keep the model as simple as possible, it is considered that the processor company produces the bulk wine and bottles it as well. So, it is responsible for receiving the grapes, production of bulk wine, storage, processing, analyzing, bottling, packing, and shipping of the final product. In the scenario of the simulation, for this company it is not clear in the beginning which grape has high or low quality. It produces the wine with "first in first out" principle. So, it consumes firstly the grape that was received first. 
The processor company should record the information such as receiving the grape, their variety, and identity of suppliers (farmers/grape growers), as well as the details of transformation from grape to wine including making the juice, the results of chemical analysis, bottling, packaging, as well as internal business processes.

Distributor-Distributor is responsible for receiving the final products, to store, to manage, and to pack them. It may need re-packing as well if required. Similarly to other actors, the distributor records all the information.

Wholesaler-Wholesaler receives the bulk quantity of the final product from the distributor. It collects the goods, stores, and distributes to retail shops. It gets the financial risk as well and records the data related to the goods.

Retailer-Retailer buys goods from the wholesaler, gets the pallets and cartons, then sells to consumers by units. It has similar responsibilities to the distributor. In order to be maintained, the whole "road" of the final product and simplicity of tracking in the case of an unsatisfying good, it is crucially important to record all the information by all actors.

The idea is that in the case of blockchain-based supply chain, all the information from each actor should be recorded (or linked) on the distributed ledger. Differently to the traditional supply chain, when the supplier is identified, the containers of material and of the bulk wine should be codified; the final product should have the unique identity number (QR code); the pallets and cartons should be codified as well and should be linked to each other in a way that the information line is not interrupted for tracking back the product.

The simulation examines traditional and blockchain-based supply chains. The architecture is the same for each model:

1. Grapes are allocated randomly on the map (Figure 3).

2. Farmers collect the grape and provide the processor with it (Figure 5a).

3. The processor company produces the final product. The wine quality chart in Figure 4 demonstrates in details the information about the production process. With the red line, the availability of the grapes is shown. When the processor company starts to produce the wine, the quantity of available grapes decreases and increases the quantity of produced wines. With the orange line, the low-quality wine is expressed and with the green line the high-quality wine. The gray area shows the accumulative quantity of all produced wines.

The processor company does not know which grape has high or low quality. In Figure $5 b$, the low-quality wine is shown with the orange color circles, while the high quality with the green color circles. The processor company starts producing the wine with the first received grapes (in the model, one symbol of the grape represents the material for producing one bottle of wine). Then it dispatches to the distributor.

Distributor sells them to the wholesaler and the retailer buys from the wholesaler (Figure 5c).

In the event that the low-quality wine is founded by consumer, the retailer returns back the unsatisfying product. In order to avoid returning back all the wine supplied by this processor company, the provenience of the used grape should be investigated. So, the high-quality products will not be re-called from the market. Figure 4 shows the passes from retailer to producer through wholesaler and distributor, and then the processor company finds the farmer who was provided with the low-quality grape.

In the simulation, there are two scenarios of the supply chain-one is the traditional, and the second, blockchain-based. The pictures obtained from the software represent the visualization of stakeholders' interaction and their activities along whole supply chain. Precisely, they describe the process of collecting the grape, selling to the producer company, producing the bottled wine, and supplying to the end consumers through distributor, wholesaler, and retailer (Figure 5), as well as the process of exposing the existence of low-quality wine by a consumer and detecting all the harmful bottles of wine through tracking them back till the supplier of the low-quality grape (Figure 6). Apparently, tracing and tracking back the product till its primary supplier takes time. The difference is the time units for each scenario. The proportion of the time to re-call the low-quality wine for 
each item in blockchain-based and traditional supply chains is about 1:300,000 calculated based on the work of Hackett R. [106].

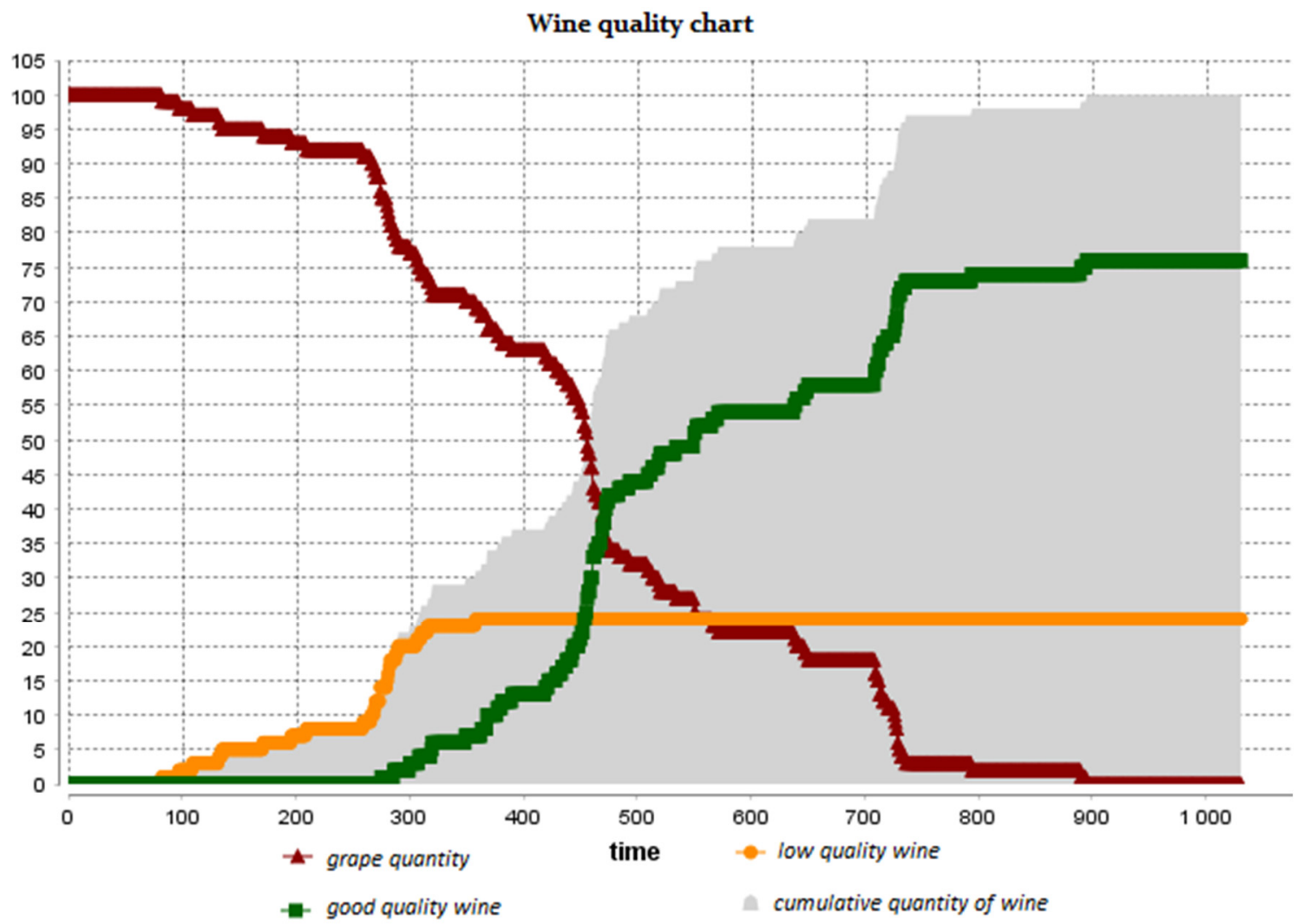

Figure 4. The wine quality chart.
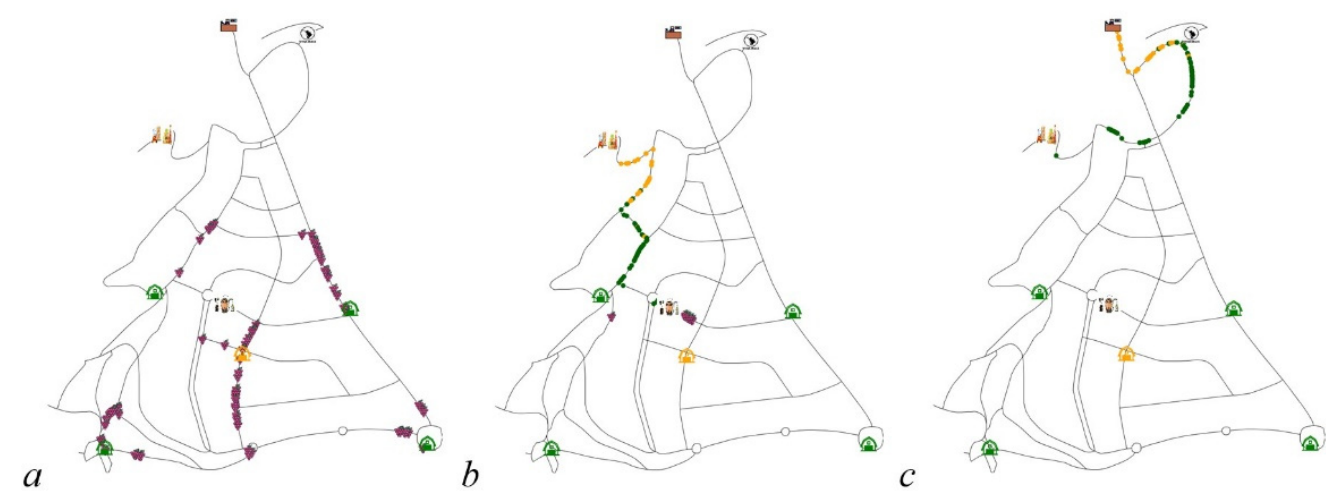

Figure 5. The path from vineyard to retailer. (a) path from wineyards to grapegrowers, producer company and distributor; (b) path from producer company from distributor; (c) path from distributor to wholsaler and retailer. 

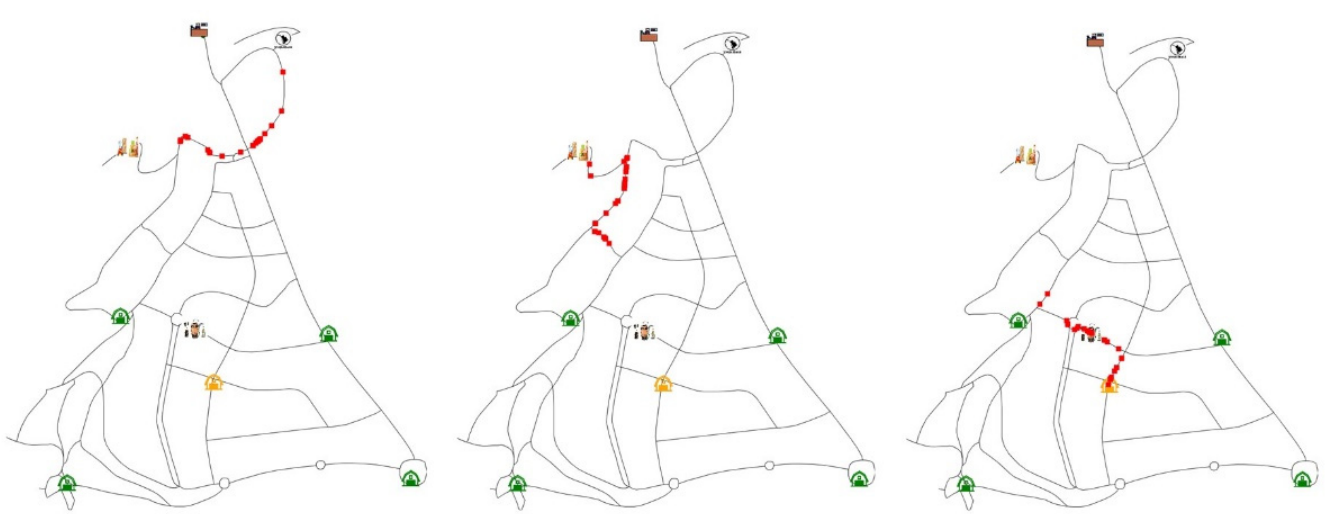

Figure 6. Tracking back the low-quality wine.

\subsection{Discussions about Outputs of the Model and Simulation "Wine Roads"}

The results for both simulations are shown in Figure 7. The charts express the time units needed to identify and re-call the low-quality products from retail shop.

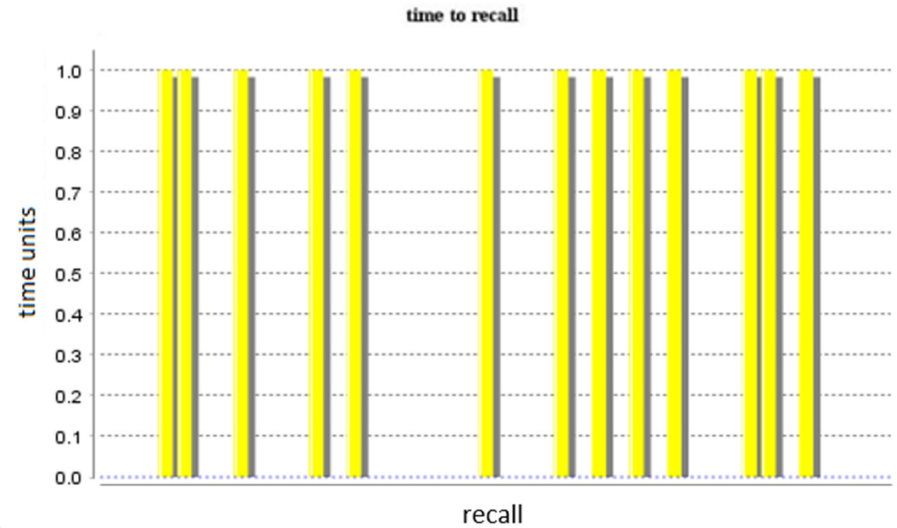

(a)

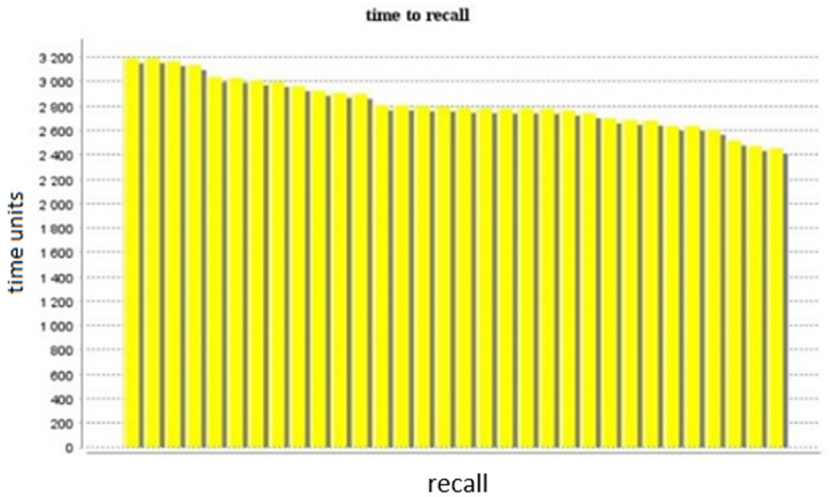

(b)

Figure 7. Time to re-call: (a)—traditional supply chain; (b)—blockchain-based supply chain.

It is evident that the time for re-call is considerably low in the case of blockchainbased supply chains. Considering the literature [10,76], it should be caused because of the complexity of the traditional ways of tracing the products-simplicity that BCT offers for this issue. In the traditional scenario, traceability is limited since the data is isolated on the organizational level. What the blockchain does is that it gathers the information in the shared ledger. It provides the transparency of all processes and gives the opportunity to track and trace the product over multiple tiers [107]. As a result, in the case of re-call, BCT eliminates uncertainty; it is clear which particular product is damaged 
or counterfeited, consequently, and targeted actions can be performed in order to avoid large-scale destructive outcomes.

As for the recall case in the traditional supply chain, there is a necessity for human involvement in tracing the products [108]. Ellie Collier [109] published the procedures for product recall. It includes 10 steps: (1) Decide if the Food Needs to be Recalled; (2) Create a Food Recall Team; (3) Gather Information on the Food Safety Incident; (4) Notify the Relevant Authorities; (5) Set Apart Affected Products in your Control; (6) Notify Consumers; (7) Monitor Progress; (8) Control Recalled Products; (9) Dispose of Recalled Products; (10) Fix the Cause of the Recall. The most time-consuming step is the information gathering. It intends to gain different kinds of information, including (a) production records, (b) sales records, (c) employees, (d) suppliers, (e) complaints, (f) audit, and (g) sample analysis, from various internal and external sources. The information is scattered among different actors, there is no shared database. It is not impossible but it may take weeks or months to determine which particular products, in which phase of the supply chain, and where they have been contaminated [110].

If the contaminated or forged product come out on the market, the solution lies in timely detecting and preventing of spreading them. If hazardous products on the market are not detected and identified timely, it will result in raised health problems or even death for the people, higher healthcare costs for governments, increased costs (meaning higher quantity of lost, re-called goods, and the cost of re-call), and lost reputation for producers $[5,6,10,76]$.

\subsection{Overall Discussion}

The findings show how effective blockchain diffusion can be in the wine supply chain in terms of information sharing and time and costs of tracking back the products.

The work portrayed the BCT and described its characteristics and different aspects for its implementation in agri-food supply chain. The comparison between traditional and non-traditional supply chain highlighted that, thanks to its transparent and immutable nature, $\mathrm{BCT}$ has the ability to minimize disorganization and inefficiencies along the supply chain that may cause disastrous results $[5,6]$. Indeed, BCT considerably diminishes the time necessary for identifying falsified or contaminated products and for removing from the trade all and only that product, also for tracing the producer and its suppliers.

Using a particular case study methodology by Yin [91], there is described a simplified model of wine supply chain in the article. It reviews all major activities that happen in real time in the industry. These activities are as follows: grape growing; wine production, its bottling and packaging; distribution; and wholesale and retail selling of the final products. Also, the model includes the act of returning back the hazardous product by the final consumer, and then identifying similar products and their origin tracking.

Through ABMs and GAMA, the whole process, from grape growing to returning back the hazardous item, is clearly visualized. Additionally, GAMA graphically displays the units of time required to perform these actions. Thank to this graph, the difference between traditional and blockchain-based supply chains is abundantly clear.

It is important to note that delays in the removal of hazardous products from sale may lead to their widespread consumption, deteriorating consumer health, economic pressures on the healthcare system as well as on the manufacturer, and damage to the manufacturer's reputation $[10,76]$.

\section{Conclusions}

The BCT has a huge potential to transform and modernize a lot of industries, especially the wine supply chain. In the agri-food sector, BCT makes the supply chain more transparent and empowers the delivery of high-quality foods with decreasing social and environmental impacts [111]. It encourages a transparent system that benefits various stakeholders, particularly the consumers, giving them the ability to know all the necessary information about the product. The benefit of this accurate information is ample for manu- 
facturers, suppliers, and retailers as well. Blockchain is a useful tool to ensure a traceability system and to protect the production from any type of fraud and contamination. Therefore, the ability to trace and track the product from supplier to consumer makes significant difference for consumers' health conditions and even between life and death, consequently, for the affected businesses' success.

Additionally, BCT considerably simplifies sharing information between actors along the supply chain and digitizes the processes that give the possibility to trace and track the product in a significantly short time and with low costs.

Therefore, the transparent nature of BCT and its ability to track products along the whole supply chain gives the opportunity to identify all and only the contaminated products in time, and consequently to call back from the market not the whole production but the hazardous ones. This reduces food waste, transportation needs towards the market and back, and, therefore, the use of natural resources related to harmful environmental effects.

The adoption of blockchain technology also has repercussions in terms of social impact thanks to the creation of new business models, the reorganization of existing models, and the introduction of new systems and new skills. The BCT adoption presupposes, in fact, the involvement of various stakeholders operating along the supply chain who will operate according to a virtuous cycle, engaging in peer-to-peer transactions, reducing corruption and increasing accountability, and creating value for the firms and the local communities as a whole. Additionally, BCT adoption can promote ethical issues, like fair-trade and animal welfare thanks to an inclusive development ensuring the access of small owners in a better market and ensuring safe payments or financing possibilities (e.g., FairFood, AgriLedger).

The limitation of this study can be the fact that it looks into the hazardous products' re-call process from the market from a time perspective. It will be interesting to investigate the financial aspects. Precisely, the further development of this paper and our future research objective is to compare the industry and healthcare costs of re-calling back the contaminated products in the different scenarios for traditional and blockchain-based supply chains.

Author Contributions: Conceptualization, N.A. and R.S.; methodology, N.A. and M.F.; software, R.S.; validation, N.A. and R.S.; formal analysis, N.A.; investigation, N.A. and M.F.; resources, N.A., R.S.; data curation, N.A.; writing — original draft preparation, N.A., M.F.; writing—review and editing, N.A., M.F. and C.T.; visualization, N.A.; supervision, R.S. and C.T.; project administration, R.S.; funding acquisition. All authors have read and agreed to the published version of the manuscript.

Funding: This research received no external funding.

Institutional Review Board Statement: Not applicable.

Informed Consent Statement: Not applicable.

Data Availability Statement: The data used for the subject analysis and for the input of model are scholarly articles available on the databases such as Scopus, WoS, Google Scholar; Software used in the research is open source and available here: https://gama-platform.org/download (accessed on 1 September 2021).

Conflicts of Interest: The authors declare no conflict of interest.

\section{References}

1. Mollet, B.; Rowland, I. Functional foods: At the frontier between food and pharma. Curr. Opin. Biotechnol. 2002, 13, 483-485. [CrossRef]

2. Young, Y. Functional foods and the European consumer. In Functional Foods. II. Claims and Evidence; Buttriss, J., Saltmarsh, M., Eds.; The Royal Society of Chemistry: London, UK, 2000.

3. D'Alessandro, A.; Zolla, L. We are what we eat: Food safety and proteomics. J. Proteome Res. 2012, 11, 26-36. [CrossRef]

4. WHO. Food Safety: Key Facts 2020. Available online: https://www.who.int/news-room/fact-sheets/detail/food-safety\#: $\sim\{\}:$ text=An\%20estimated $\% 20600 \% 20$ million $\% 20 \%$ E2\%80\%93\%20almost, healthy $\% 201$ ife $\% 20 y e a r s \% 20$ (DALYs) (accessed on 23 September 2021).

5. Kadariya, J.; Smith, T.C.; Thapaliya, D. Staphylococcus aureus and staphylococcal food-borne disease: An ongoing challenge in public health. BioMed Res. Int. 2014, 2014, 827965. [CrossRef] [PubMed] 
6. Scharff, R.L. Economic burden from health losses due to foodborne illness in the united states. J. Food Prot. 2012, 75, 123-131. [CrossRef] [PubMed]

7. Astill, J.; Fraser, E.; Dara, R.; Sharif, S. Detecting and Predicting Emerging Disease in Poultry with the Implementation of New Technologies and Big Data: A Focus on Avian Influenza Virus. Front. Vet. Sci. 2018, 5, 263. [CrossRef] [PubMed]

8. Esteki, M.; Regueiro, J.; Simal-Gándara, J. Tackling fraudsters with global strategies to expose fraud in the food chain. Compr. Rev. Food Sci. Food Saf. 2019, 18, 425-440. [CrossRef]

9. Saberi, S.; Kouhizadeh, M.; Sarkis, J.; Shen, L. Blockchain technology and its relationships to sustainable supply chain management. Int. J. Prod. Res. 2019, 57, 2117-2135. [CrossRef]

10. Kshetri, N.; Loukoianova, E. Blockchain adoption in supply chain networks in asia. IT Prof. 2019, 21, 11-15. [CrossRef]

11. Martins-Lopes, P.; Gomes, S. Olive oil traceability through DNA markers. Olive Consum. Health 2012, 211-224. Available online: https: / / www.scopus.com/record / display.uri?eid=2-s2.0-84895403310\&origin=inward\&txGid=eec05861da4577b2b9a6 f86bcf458732 (accessed on 23 September 2021).

12. Camin, F.; Boner, M.; Bontempo, L.; Fauhl-Hassek, C.; Kelly, S.D.; Riedl, J.; Rossmann, A. Stable isotope techniques for verifying the declared geographical origin of food in legal cases. Trends Food Sci. Technol. 2017, 61, 176-187. [CrossRef]

13. Durante, C.; Bertacchini, L.; Cocchi, M.; Manzini, D.; Marchetti, A.; Rossi, M.C.; Sighinolfi, S.; Tassi, L. Development of 87Sr/86Sr maps as targeted strategy to support wine quality. Food Chem. 2018, 255, 139-146. [CrossRef]

14. Hill, G.N.; Beresford, R.M.; Evans, K.J. Tools for accurate assessment of botrytis bunch rot (Botrytis cinerea) on wine grapes. N. Z. Plant Prot. 2010, 63, 174-181. [CrossRef]

15. Moreno-Arribas, M.V.; Polo, M.C. Wine Chemistry and Biochemistry; Springer: New York, NY, USA, 2009. [CrossRef]

16. Yin, S.; Liu, L.; Hou, J. A multivariate statistical combination forecasting method for product quality evaluation. Inf. Sci. 2016, 355-356, 229-236. [CrossRef]

17. Fotakis, C.; Kokkotou, K.; Zoumpoulakis, P.; Zervou, M. NMR metabolite fingerprinting in grape derived products: An overview. Food Res. Int. 2013, 54, 1184-1194. [CrossRef]

18. Fernández-Novales, J.; Sánchez, M.; López, M.; Garcúa-Mesa, J.; Ramúrez, P. Feasibility of using a miniature fiber optic UV-VISNIR spectrometer to assess total polyphenol index, color intensity and volumic mass in red wine fermentations. J. Food Process. Eng. 2011, 34, 1028-1045. [CrossRef]

19. Zhang, Q.; Chen, B. Research progress of four sulfur compounds related to red wine flavor. Sci. Agric. Sin. 2020, 53, 1029-1045. [CrossRef]

20. Exposito, I.; Cuinas, I.; Gay-Fernandez, J.A. Efficient traceability solutions in the wine production by RFID and WSN. In Proceedings of the 2013 7th European Conference on Antennas and Propagation (EuCAP), Gothenburg, Sweden, 8-12 April 2013; pp. 3539-3542.

21. Galvez, J.F.; Mejuto, J.C.; Simal-Gandara, J. Future challenges on the use of blockchain for food traceability analysis. TrAC Trends Anal. Chem. 2018, 107, 222-232. [CrossRef]

22. Shahid, A.; Almogren, A.S.; Javaid, N.; Al-Zahrani, F.A.; Zuair, M.; Alam, M. Blockchain-Based Agri-Food Supply Chain: A Complete Solution. IEEE Access 2020, 8, 69230-69243. [CrossRef]

23. Tian, F. A supply chain traceability system for food safety based on HACCP, blockchain \& internet of things. In Proceedings of the 14th International Conference on Services Systems and Services Management (ICSSSM 2017), Dalian, China, 16-18 June 2017. [CrossRef]

24. Aiello, G.; Enea, M.; Muriana, C. The expected value of the traceability information. Eur. J. Oper. Res. 2015, 244, 176-186. [CrossRef]

25. Beaman, R.; Cellinese, N. Mass digitization of scientific collections: New opportunities to transform the use of biological specimens and underwrite biodiversity science. ZooKeys 2012, 209, 7-17. [CrossRef]

26. Adamashvili, N.; Fiore, M.; Contò, F.; La Sala, P. Ecosystem for Successful Agriculture. Collaborative Approach as a Driver for Agricultural Development. Eur. Countrys. 2020, 12, 242-256. [CrossRef]

27. Caro, M.P.; Ali, M.S.; Vecchio, M.; Giaffreda, R. Blockchain-based traceability in agri-food supply chain management: A practical implementation. In Proceedings of the 2018 IoT Vertical and Topical Summit on Agriculture-Tuscany (IOT Tuscany), Tuscany, Italy, 8-9 May 2018; pp. 1-4. [CrossRef]

28. Huck, C.W.; Pezzei, C.K.; Huck-Pezzei, V.A. An industry perspective of food fraud. Curr. Opin. Food Sci. $2016,10,32-37$. [CrossRef]

29. Alketbi, A.; Nasir, Q.; Talib, M.A. Blockchain for government services-use cases, security benefits and challenges. In Proceedings of the 2018 15th Learning and Technology Conference (L and T), Jeddah, Saudi Arabia, 25-26 February 2018; pp. 112-119. [CrossRef]

30. Meroni, G.; Plebani, P. Combining artifact-driven monitoring with blockchain: Analysis and solutions. In Advanced Information Systems Engineering Workshops; CAiSE 2018; Lecture Notes in Business Information Processing; Matulevičius, R., Dijkman, R., Eds.; Springer: Cham, Switzerland, 2018; p. 316. [CrossRef]

31. Stubbs, M. Big Data in U.S. Agriculture, Congressional Research Service. 2016. Available online: https://sgp.fas.org/crs/misc/ R44331.pdf (accessed on 23 September 2021).

32. Raikwar, M.; Gligoroski, D.; Kralevska, K. SoK of Used Cryptography in Blockchain. IEEE Access 2019, 7, 148550-148575. [CrossRef] 
33. Condos, J.; Sorrell, W.H.; Donegan, S.L. Blockchain Technology: Opportunities and Risks. 2016. Available online: https: / / legislature.vermont.gov/assets/Legislative-Reports/blockchain-technology-report-final.pdf (accessed on 23 September 2021).

34. Smith, J.; Tennison, J.; Wells, P.; Fawcett, J.; Harrison, S. Applying blockchain technology in global data infrastructure. Open Data Inst. 2016. Available online: https:/ / theodi.org/article/applying-blockchain-technology-in-global-data-infrastructure-2/ (accessed on 23 September 2021).

35. Caseau, Y.; Soudoplatoff, S. The Blockchain, or Distributed Trust. Fond. Pour L'innovation Polit. 2016. Available online: https: / / oiipdf.com/yves-caseau-and-serge-soudoplatoff-the-blockchain-or-distributed-trust (accessed on 23 September 2021).

36. Hon, W.K.; Palfreyman, J.; Tegart, M. Distributed Ledger Technology and Cybersecurity: Improving Information Security in the Financial Sector; Technical Report; European Union Agency For Network and Information Security: Heraklion, Greece, 2016.

37. Anderberg, A.; Andonova, E.; Bellia, M.; Calès, L.; Inamorato dos Santos, A.; Kounelis, I.; Nai Fovino, I.; Petracco Giudici, M.; Papanagiotou, E.; Sobolewski, M.; et al. Blockchain Now and Tomorrow: Assessing Multidimensional Impacts of Distributed Ledger Technologies; Report EUR 29813 EN; Nascimento, S., Pólvora, A., Eds.; Publications Office of the European Union: Luxembourg, 2019; ISBN 978-92-76-08977-3. [CrossRef]

38. Zhang, Z; Zhao, L. A design of digital rights management mechanism based on blockchain technology. In Blockchain-ICBC 2018; Chen, S., Wang, H., Zhang, L.J., Eds.; ICBC 2018; Lecture Notes in Computer Science; Springer: Cham, Switzerland, 2018; Volume 10974. [CrossRef]

39. Zhang, K.; Jacobsen, H. Towards dependable, scalable, and pervasive distributed ledgers with blockchains. In Proceedings of the International Conference on Distributed Computing Systems, Vienna, Austria, 2-5 July 2018; pp. 1337-1346. [CrossRef]

40. Reyna, A.; Martín, C.; Chen, J.; Soler, E.; Díaz, M. On blockchain and its integration with IoT. challenges and opportunities. Future Gener. Comput. Syst. 2018, 88, 173-190. [CrossRef]

41. Haber, S.; Stornetta, W.S. How to time-stamp a digital document. J. Cryptol. 1991, 3, 99-111. [CrossRef]

42. Nakamoto, S. Bitcoin: A Peer-to-Peer Electronic Cash System. 2008. Available online: https://bitcoin.org/bitcoin.pdf. (accessed on 23 September 2021).

43. Zhao, G.; Liu, S.; Lopez, C.; Lu, H.; Elgueta, S.; Chen, H.; Boshkoska, B.M. Blockchain technology in agri-food value chain management: A synthesis of applications, challenges and future research directions. Comput. Ind. 2019, 109, 83-99. [CrossRef]

44. Kamble, S.S.; Gunasekaran, A.; Sharma, R. Modeling the blockchain enabled traceability in agriculture supply chain. Int. J. Inf. Manag. 2020, 52, 101967. [CrossRef]

45. Malik, S.; Kanhere, S.S.; Jurdak, R. ProductChain: Scalable blockchain framework to support provenance in supply chains. In Proceedings of the 2018 IEEE 17th International Symposium on Network Computing and Applications (NCA), Cambridge, MA, USA, 1-3 November 2018. [CrossRef]

46. Gourisetti, S.N.G.; Mylrea, M.; Patangia, H. Evaluation and demonstration of blockchain applicability framework. IEEE Trans. Eng. Manag. 2020, 67, 1142-1156. [CrossRef]

47. Kennedy, J. \$1.4bn Investment in Blockchain Start-Ups in Last 9 Months, Says PwC Expert. 2016. Available online: https: //www.siliconrepublic.com/start-ups/blockchain-pwc-investment (accessed on 23 September 2021).

48. Okada, H.; Yamasaki, S.; Bracamonte, V. Proposed classification of blockchains based on authority and incentive dimensions. In Proceedings of the International Conference on Advanced Communication Technology (ICACT), Pyeongchang, Korea, 19-22 February 2017; pp. 593-597. [CrossRef]

49. Fabiano, N. Internet of things and blockchain: Legal issues and privacy. the challenge for a privacy standard. In Proceedings of the 2017 IEEE International Conference on Internet of Things (iThings) and IEEE Green Computing and Communications (GreenCom) and IEEE Cyber, Physical and Social Computing (CPSCom) and IEEE Smart Data (SmartData), Exeter, UK, 21-23 June 2017; pp. 727-734. [CrossRef]

50. Hebert, C.; Di Cerbo, F. Secure blockchain in the enterprise: A methodology. Pervasive Mob. Comput. 2019, 59, 101038. [CrossRef]

51. Chaudhry, N.; Yousaf, M.M. Consensus algorithms in blockchain: Comparative analysis, challenges and opportunities. In Proceedings of the 2018 International Conference on Open Source Systems and Technologies (ICOSST), Lahore, Pakistan, 19-21 December 2018; pp. 54-63. [CrossRef]

52. Desai, H.; Kantarcioglu, M.; Kagal, L. A hybrid blockchain architecture for privacy-enabled and accountable auctions. In Proceedings of the 2019 2nd IEEE International Conference on Blockchain (Blockchain), Atlanta, GA, USA, 14-17 July 2019; pp. 34-43. [CrossRef]

53. Regulation (EU). 2018/1807 of the European Parliament and of the Council of 14 November 2018 on a Framework for the Free Flow of Non-Personal Data in the European Union. Available online: https:/ / eur-lex.europa.eu/legal-content/EN/TXT/?uri= celex\%3A32018R1807 (accessed on 23 September 2021).

54. Sheldon, M.D. A primer for information technology general control considerations on a private and permissioned blockchain audit. Curr. Issues Audit. 2019, 13, A15-A29. [CrossRef]

55. Terzi, S.; Zacharaki, A.; Nizamis, A.; Votis, K.; Ioannidis, D.; Tzovaras, D.; Stamelos, I. Transforming the supply-chain management and industry logistics with blockchain smart contracts. In Proceedings of the 23rd Pan-Hellenic Conference on Informatics (PCI'19); Association for Computing Machinery: New York, NY, USA, 2019; pp. 9-14. [CrossRef]

56. Malik, S.; Dedeoglu, V.; Kanhere, S.S.; Jurdak, R. TrustChain: Trust management in blockchain and iot supported supply chains. In Proceedings of the 2019 2nd IEEE International Conference on Blockchain (Blockchain), Atlanta, GA, USA, 14-17 July 2019; pp. 184-193. [CrossRef] 
57. Gemeliarana, I.G.A.K.; Sari, R.F. Evaluation of proof of work (POW) blockchains security network on selfish mining. In Proceedings of the 2018 International Seminar on Research of Information Technology and Intelligent Systems (ISRITI), Yogyakarta, Indonesia, 21-22 November 2018; pp. 126-130. [CrossRef]

58. Yao, Z.; Pan, H.; Si, X.; Zhu, W. Decentralized access control encryption in public blockchain. In Blockchain and Trustworthy Systems; Zheng, Z., Dai, H.N., Tang, M., Chen, X., Eds.; BlockSys 2019; Communications in Computer and Information Science; Springer: Singapore, 2019; Volume 1156. [CrossRef]

59. Falazi, G.; Khinchi, V.; Breitenbücher, U.; Leymann, F. Transactional properties of permissioned blockchains. SICS Softw. Intensive Cyber-Phys. Syst. 2020, 35, 49-61. [CrossRef]

60. Buterin, V. On Public and Private Blockchains. 2015. Available online: https://blog.ethereum.org/2015/08/07/on-public-andprivate-blockchains / (accessed on 1 December 2020).

61. Zheng, Z.; Xie, S.; Hongning, D.; Xiangping, C.; Huaimin, W. An overview of blockchain technology: Architecture, consensus, and future trands. In Proceedings of the IEEE 6th international congress on Big Data, Honolulu, HI, USA, 25-30 June 2017; pp. 557-564. [CrossRef]

62. El Bilali, H.; Bottalico, F.; Ottomano Palmisano, G.; Capone, R. Information and Communication Technologies for Smart and Sustainable Agriculture. In 30th Scientific-Experts Conference of Agriculture and Food Industry; Brka, M., Omanović-Mikličanin, E., Karić, L., Falan, V., Toroman, A., Eds.; AgriConf 2019; IFMBE Proceedings; Springer: Cham, Switzerland, 2020; Volume 78. [CrossRef]

63. Lin, W.; Huang, X.; Fang, X.; Wang, V.; Hua, Y.; Wang, J.; Yin, H.; Yi, D.; Yau, L. Blockchain Technology in Current Agricultural Systems: From Techniques to Applications. IEEE Access 2020, 8, 143920-143937. [CrossRef]

64. Jabir, B.; Falih, N. Digital agriculture in morocco, opportunities and challenges. In Proceedings of the 6th International Conference on Optimization and Applications (ICOA 2020), Beni Mellal, Morocco, 20-21 April 2020; pp. 1-5. [CrossRef]

65. Ciruela-Lorenzo, A.M.; Del-Aguila-Obra, A.R.; Padilla-Meléndez, A.; Plaza-Angulo, J.J. Digitalization of Agri-Cooperatives in the Smart Agriculture Context. Proposal of a Digital Diagnosis Tool. Sustainability 2020, 12, 1325. [CrossRef]

66. Jennath, H.S.; Adarsh, S.; Anoop, V.S. Distributed IoT and Applications: A Survey. In Integrated Intelligent Computing, Communication and Security; Krishna, A., Srikantaiah, K., Naveena, C., Eds.; Studies in Computational Intelligence; Springer: Singapore, 2019; Volume 771. [CrossRef]

67. Gorshkova, N.V.; Kusmartseva, J.V. Financial Aspects of the Digital Economy Development in the Agricultural Sector. In Competitive Russia: Foresight Model of Economic and Legal Development in the Digital Age; Inshakova, A., Inshakova, E., Eds.; CRFMELD 2019; Lecture Notes in Networks and Systems; Springer: Cham, Switzerland, 2019; Volume 110. [CrossRef]

68. Demestichas, K.; Peppes, N.; Alexakis, T.; Adamopoulou, E. Blockchain in Agriculture Traceability Systems: A Review. Appl. Sci. 2020, 10, 4113. [CrossRef]

69. Song, L.; Wang, X.; Merveille, N. Research on Blockchain for Sustainable E-Agriculture. In Proceedings of the IEEE Technology \& Engineering Management Conference (TEMSCON), Novi, MI, USA, 3-6 June 2020; pp. 1-5. [CrossRef]

70. Fernandez, A.; Waghmare, A.; Tripathi, S. Agricultural Supply Chain using Blockchain. In Proceedings of International Conference on Intelligent Manufacturing and Automation; Lecture Notes in Mechanical Engineering; Vasudevan, H., Kottur, V., Raina, A., Eds.; Springer: Singapore, 2020. [CrossRef]

71. Katsikouli, P.; Wilde, A.S.; Dragoni, N.; Høgh-Jensen, H. On the Benefits and Challenges of Blockchains for Managing Food Supply Chains. J. Sci. Food Agric. 2020, 101, 2175-2181. [CrossRef] [PubMed]

72. Caballero, R.; Rivera, B. Blockchain: An Alternative to Enable Traceability in the Agricultural Supply Chain in Panama. In Proceedings of the 7th International Engineering, Sciences and Technology Conference (IESTEC), Panama, Panama, 9-11 October 2019; pp. 46-51. [CrossRef]

73. Bermeo-Almeida, O.; Cardenas-Rodriguez, M.; Samaniego-Cobo, T.; Ferruzola-Gómez, E.; Cabezas-Cabezas, R.; Bazán-Vera, W. Blockchain in Agriculture: A Systematic Literature Review. In Technologies and Innovation. CITI 2018. Communications in Computer and Information Science; Valencia-García, R., Alcaraz-Mármol, G., Del Cioppo-Morstadt, J., Vera-Lucio, N., Bucaram-Leverone, M., Eds.; Springer: Cham, Switzerland, 2018; Volume 883. [CrossRef]

74. European Parliament and of the Council. European Parliament Regulation (EC) No 178/2002; Official Journal of the European Union: Brussels, Belgium, 2002; pp. 1-24.

75. Mirabelli, G.; Solina, V. Blockchain and Agricultural Supply Chains Traceability: Research Trends and Future Challenges. Procedia Manuf. 2020, 42, 414-421. [CrossRef]

76. Pouliot, S.; Sumner, D.A. Traceability, recalls, industry reputation and product safety. Eur. Rev. Agric. Econ. 2013, 40, 121-142. [CrossRef]

77. Dave, D.; Parikh, S.; Patel, R.; Doshi, N. A Survey on Blockchain Technology and its Proposed Solutions. Procedia Comput. Sci. 2019, 160, 740-745. [CrossRef]

78. Umamaheswari, S.; Sreeram, S.; Kritika, N.; Jyothi Prasanth, D.R. BIoT: Blockchain Based IoT for Agriculture. In Proceedings of the 1th International Conference on Advanced Computing (ICoAC), Chennai, India, 2019; pp. 324-327. [CrossRef]

79. Tian, F. An agri-food supply chain traceability system for China based on RFID \& Blockchain technology. In Proceedings of the 13th International Conference on Service Systems and Service Management (ICSSSM), Kunming, China, 24-26 June 2016; pp. 1-6.

80. Khan, P.W.; Byun, Y.; Park, N. IoT-Blockchain Enabled Optimized Provenance System for Food Industry 4.0 using Advanced Deep Learning. Sensors 2020, 20, 2990. [CrossRef] 
81. FAO; International Telecommunication Union. E-agriculture in Action: Blockchain for Agriculture, Opportunity and Challenges; FAO: Bangok, Thailand, 2019.

82. Yang, H.; Xiong, S.; Frimpong, S.A.; Zhang, M. A Consortium Blockchain-Based Agricultural Machinery Scheduling System. Sensors 2020, 20, 2643. [CrossRef] [PubMed]

83. Fiore, M.; Silvestri, R.; Contò, F.; Pellegrini, G. Understanding the relationship between green approach and marketing innovations tools in the wine sector. J. Clean. Prod. 2017, 142, 4085-4091. [CrossRef]

84. Fiore, M.; Alaimo, L.S.; Chkhartishvili, N. The Amazing Bond among Wine Consumption, Health and Hedonistic Well-being. Br. Food J. 2019, 122, 2707-2723. [CrossRef]

85. Contò, F.; Santini, C.; La Sala, P.; Fiore, M. Reducing Information Gap and Increasing Market Orientation in the Agribusiness Sector: Some Evidences from Apulia Region. Recent Pat. Food Nutr. Agric. 2016, 8, 48-54. [CrossRef]

86. Fiore, M. Direct Selling in the Wine Sector: Lessons from Cellars in Italy's Apulia Region. Br. Food J. 2016, 118, 1946-1959. [CrossRef]

87. Valmori, I. Enology: La Blockchain Pubblica e Gratuita a Garanzia Del Vino. AgroNotizie-Le Novità Per L'agricoltura 2018. Available online: https:/ /agronotizie.imagelinenetwork.com/agricoltura-economia-politica/2018/04/19/enology-la-blockchainpubblica-e-gratuita-a-garanzia-del-vino/58387 (accessed on 23 September 2021).

88. Burgers, C.; Brugman, B.C.; Boeynaems, A. Systematic literature reviews: Four applications for interdisciplinary research. J. Pragmat. 2019, 145, 102-109. [CrossRef]

89. Recker, J. Scientific Research in Information System. In A Beginner's Guide; Springer: Berlin, Germany, 2013.

90. Stake, R.E. The Art of Case Study Research; Sage: Thousand Oaks, CA, USA, 1995.

91. Yin, R.K. Case Study Research: Design and Methods, 3rd ed.; Sage: Thousand Oaks, CA, USA, 2003.

92. Miles, M.B.; Huberman, A.M. Qualitative Data Analysis: An Expanded Source Book, 2nd ed.; Sage: Thousand Oaks, CA, USA, 1994.

93. Patton, M. Qualitative Evaluation and Research Methods, 2nd ed.; SAGE Publications, Inc.: Newbury Park, CA, USA, 1990.

94. Eisenhardt, K.M. Better stories and better constructs: The case for rigor and comparative logic. Acad. Manag. Rev. 1991, 16, 620-627. [CrossRef]

95. Baxter, P.; Jack, S. Qualitative case study methodology: Study design and implementation for novice researchers. Qual. Rep. 2008, 13, 544-559. [CrossRef]

96. Ketokivi, M.; Choi, T. Renaissance of case research as a scientific method. J. Oper. Manag. 2014, 32, 232-240. [CrossRef]

97. Pagell, M.; Wu, Z. Building a more complete theory of sustainable supply chain management using case studies of 10 exemplars. J. Supply Chain. Manag. 2009, 45, 37-56. [CrossRef]

98. Eisenhardt, K.M. Building theories from case study research. Acad. Manag. Rev. 1989, 14, 532-550. [CrossRef]

99. Sabz Ali Pour, F.; Tatar, U.; Gheorghe, A. Agent-Based Model of Sand Supply Governance Employing Blockchain Technology. In Proceedings of the SpringSim'18: 2018 Spring Simulation Multiconference, Baltimore, MD, USA, 15-18 April 2018.

100. Crooks, A.T.; Heppenstall, A. Introduction to Agent-Based Modeling. In Agent-Based Models of Geographical Systems; Heppenstall, A., Crooks, A.T., See, L.M., Batty, M., Eds.; Springer: New York, NY, USA, 2012; pp. 85-108.

101. Crooks, A.; Heppenstall, A.J.; Malleson, N. Agent-Based Modeling. In Comprehensive Geographic Information Systems; Elsevier: Amsterdam, The Netherlands, 2018; pp. 218-243. [CrossRef]

102. Schieritz, N.; GroBler, A. Emergent structures in supply chains-A study integrating agent-based and system dynamics modeling. In Proceedings of the 36th Annual Hawaii International Conference on System Sciences, Big Island, HI, USA, 6-9 January 2003 ; p. 9. [CrossRef]

103. Taillandier, P.; Grignard, A.; Marilleau, N.; Philippon, D.; Huynh, Q.N.; Gaudou, B.; Drogoul, A. Participatory Modeling and Simulation with the GAMA platform. J. Artif. Soc. Soc. Simul. 2019, 22, 3. [CrossRef]

104. Taillandier, P.; Gaudou, B.; Grignard, A.; Huynh, Q.N.; Marilleau, N.; Caillou, P.; Philippon, D.; Drogoul, A. Building, composing and experimenting complex spatial models with the GAMA platform. Geoinformatica 2019, 23, 299-322. [CrossRef]

105. Grignard, A.; Drogoul, A. Agent-based visualization: A real-time visualization tool applied both to data and simulation outputs. In Proceedings of the AAAI-17 Workshop on Human-Machine Collaborative Learning, San Francisco, CA, USA, 4 February 2017; pp. 670-675.

106. Hackett, R. Walmart and 9 Food Giants Team Up on IBM Blockchain Plans. Fortune 2017. Available online: https:/ / fortune.com/ 2017/08/22/walmart-blockchain-ibm-food-nestle-unilever-tyson-dole/ (accessed on 23 September 2021).

107. Westerkamp, M.; Victor, F.; Küpper, A. Tracing manufacturing processes using blockchain-based token compositions. Digit. Commun. Netw. 2020, 6, 167-176. [CrossRef]

108. FAO. Aquaculture Development. 1. Good Aquaculture Feed Manufacturing Practice. 2001. Available online: http://www.fao. org/3/y1453e00.htm\#Contents (accessed on 23 September 2021).

109. Collier, E. Food Product Recall Procedure. 2019. Available online: https://www.highspeedtraining.co.uk/hub/product-recalltemplate/ (accessed on 23 September 2021).

110. Guo, M.; Liu, X.J.; Zhang, W. Using blockchain technology in human food chain provenance. In WIT Transactions on the Built Environment; WIT Press: Ashurst Lodge, UK, 2018; Volume 179, pp. 391-396. [CrossRef]

111. Rana, R.L.; Tricase, C.; De Cesare, L. Blockchain technology for a sustainable agri-food supply chain. Br. Food J. 2021, 123, 3471-3485. [CrossRef] 